\title{
Clostridium Difficile Infection (CDI) Among Egyptian Patients with Inflammatory Bowel Disease
}

\author{
Taher Ezzat Amin ${ }^{1}$ MSc., Mohamed Nusehy Al-Alfy ${ }^{2, *}$ MD, Kamel Soliman Hammad ${ }^{3}$ MD and Abd Elhalim \\ Abd-Alghany Hassabo ${ }^{2}$ MD.
}

* Corresponding Author:

Taher Ezzat Amin

taherezzatahmed@gmail.com

Received for publication November 20, 2021; Accepted Jaunary 23, 2022; Published online Jaunary 23, 2022.

Copyright The Author published by Al-Azhar University, Faculty of Medicine, Cairo, Egypt. Users have the right to read, download, copy, distribute, print, search, or link to the full texts of articles under the following conditions: Creative Commons Attribution-Share Alike 4.0 International Public License (CC $B Y-S A$ 4.0).

doi: $10.21608 /$ aimj.2022.105840.1658

${ }^{1}$ Department of Internal Medicine, Al Farafra Central Hospital, Egypt

${ }^{2}$ Department of Internal Medicine, Faculty of Medicine, Al-Azhar University, Egypt

${ }^{3}$ Department of Clinical Pathology, Faculty of Medicine, Al-Azhar University, Egypt.

\begin{abstract}
Background: Clostridium Difficile Infection (CDI) had a negative impact on inflammatory bowel disease (IBD) cases.

Aim of the work: This study was conducted to assess the prevalence of this infection in patients with IBD and to elucidate the risk factors and the impact of such infection in these cases.

Patients and Methods: We included a total of 120 subjects who were divided into two groups: the first one included 80 cases diagnosed with IBD, while the second one included 40 healthy controls. All cases were clinically assessed. Routine laboratory investigations and colonoscopy were performed for all cases. Furthermore, stool PCR for Clostridium difficile was ordered for all cases and controls.

Result: CDI rate was significantly higher in cases compared to controls, as it was detected in $16.25 \%$ and $2.5 \%$ of subjects in the same groups, respectively. On univariate analysis, old age, long disease duration, severe disease, and high CRP levels were risk factors for CDI. All of these variables remained significant on multivariate analysis apart from disease duration. Surgical intervention was needed in two CDI +ve patients, with no mortality encountered. CDI was associated with a significant increase in the duration of hospitalization compared to CDI ve patients ( 15 vs. seven days, respectively).

Conclusion: The Prevalence CDI was $16.25 \%$. Old age, long disease duration, high CRP, and high disease activity are significant risk factors of CDI in IBD patients. In addition, CDI was associated with worse IBD outcomes.
\end{abstract}

Keywords: Clostridium Difficile; Prevalence; Risk factors.
Disclosure: The authors have no financial interest to declare in relation to the content of this article. The Article Processing Charge was paid for by the authors.

Authorship: All authors have a substantial contribution to the article.

\section{INTRODUCTION}

Clostridium difficile infection (CDI) is the most common cause of antibiotic-associated diarrhea, and it is linked to a high rate of morbidity and mortality. Despite the fact that the medical community has gained a greater understanding of the epidemiology, pathophysiology, diagnosis, and treatment of this infection over the last decade, the rising prevalence and severity of CDI continue to be a challenge to many physicians. ${ }^{1,2}$

Inflammatory bowel diseases (IBD), including ulcerative colitis (UC) and Crohn's disease (CD), are relapsing inflammatory diseases that often necessitate long-term medical treatment, hospitalizations, and even surgery. ${ }^{3,} 4 \mathrm{CDI}$ is becoming more common in both primary forms of IBD, while UC patients show more susceptibility for this infection and even experience more severe consequences. $^{5}$
C. difficile toxin was thought to worsen chronic IBD and lead to relapse in some patients about three decades ago. ${ }^{6}$ Isolated case series of CDI contributing to symptomatic relapse in IBD patients have been documented since then. ${ }^{7-9}$

The most prevalent way of acquiring CDI is from environmental exposure. The most prevalent environment for CDI infection is hospitals, which raises the risk of nosocomial infection. Antibioticresistant C. difficile spores can be found on bed rails, telephones, toilets, floors, stethoscopes, and healthcare personnel's hands in any hospital setting. ${ }^{10,11}$ Also, the infection risk is increased by sharing a room with an infected patient. ${ }^{\mathbf{1 2}}$

The increased risk of this infection in IBD cases could be due to the long-term administration of steroids, immunomodulators, and antibiotics. ${ }^{13,14}$

Overall, IBD patients with CDI have a greater risk of short- and long-term negative outcomes than those who do not have CDI or who only have CDI. ${ }^{15-17}$ 
However, research on IBD patients with CDI found mixed results in terms of death and colectomy rates, length of hospital stay, and healthcare expenditures. 17-19

Therefore, this study was conducted to assess the prevalence of CDI in patients with IBD and to identify the risk factors and outcomes for developing such infection in these cases.

\section{PATIENTS AND METHODS}

This prospective case-control study was conducted at the internal medicine department of Al-Azhar University Hospitals (Sayed Galal), Cairo, Egypt. It was performed over the period from January 2019 till December 2020. Initially, the study gained approval from the Institutional Review Board of the same university, and informed oral consent was obtained from all subjects.

A total of 120 subjects were included in the study, and they were split into two groups; Cases and control groups. The former included 80 cases diagnosed with IBD (UC or CD). This group was furtherly subdivided into two subgroups based on the detection of CDI (CDI +ve and -ve subgroups). The latter included 40 age and gender-matched healthy adult controls.

We included adult subjects from either gender, aged between 18 and 65 years, presented with history and clinical manifestations of IBD for the cases group. On the other hand, we excluded subjects with the following criteria; recent antibiotic administration within the previous three months, chronic renal disease, chronic liver disease, intake of immunosuppressive drugs, HIV infection, or recent proton pump inhibitor administration.

All of the included cases were clinically assessed. The patient complaint was analyzed. In addition, the duration of the disease and the currently commenced medications were recorded. Abdominal ultrasonography was ordered for all cases to detect any complications related to IBD. Besides, laboratory investigations included complete blood count (CBC), liver function tests, serum creatinine, random blood sugar, erythrocyte sedimentation rate (ESR), and C reactive protein (CRP).

Based on clinical and laboratory criteria, the severity of IBD was estimated using Truelove and Witts Score for UC patients ${ }^{20}$ and Harvey and Bradshaw's simplified Crohn's Disease Activity Index (CDAI) score for CD patients. ${ }^{21}$

Colonoscopy was performed only for cases under sedation by an expert endoscopist. In terms of disease site, $\mathrm{CD}$ and UC phenotypes (bowel involvement) were defined using the Montreal categorization system. ${ }^{22,23}$ Multiple biopsies were obtained for histopathological examination.

CDI was confirmed by performing stool PCR (Polymerase Chain Reaction). A sterile chip of stool was removed from each sample for the PCR experiment and transported to the laboratory on dry ice for analysis. For this study, we used the BD
GeneOhm Cdiff test (BD Diagnostics, San Diego, CA). The PCR assay was carried out according to the manufacturer's instructions. Based on the result of PCR, cases were subdivided into two subgroups; the first one included CDI -ve cases while the second one included CDI +ve cases.

Our primary outcome was to detect the prevalence of CDI in IBD cases, whereas secondary outcomes included evaluation of the risk factors of CDI, along with the effect of CDI on disease outcomes.

\section{$\underline{\text { Statistical analysis }}$}

The data collected were coded, processed and analyzed with SPSS version 26 for Windows ${ }^{\circledR}$ (Statistical Package for Social Sciences) (IBM, SPSS Inc, Chicago, IL, USA). Qualitative data as number (frequency) and percent was presented. The ChiSquare test (or Fisher's exact test) made the comparison between groups. The KolmogorovSmirnov test tested quantitative data for normality. Data was shown as median \pm SD.

To compare two groups with categorical variables, Chi-Square test (or Fisher's exact test) were used. To compare two groups with normally distributed quantitative variables, independent samples (student's) t-test was used and Mann-Whitney U-test was used if the data were abnormally distributed.

Univariate and multivariate logistic regression analysis were used to identify the dependent and independent risk predictors of binary categorical outcome. For all tests, $\mathrm{P}$ values $<0.05$ are considered significant.

\section{RESULTS}

Starting with comparing cases to controls, age and gender showed no significant difference between cases and controls. However, In the same groups, BMI showed a substantial decrease in cases compared to controls $(\mathrm{p}=0.035)$.

Regarding CBC parameters, hemoglobin showed a significant drop in cases compared to controls (8.3 vs. $11.33 \mathrm{~g} / \mathrm{dl}$ respectively $-\mathrm{p}=0.015)$, while leucocytic count showed a significant increase in the same group (11.71 vs. 9.09 respectively $-\mathrm{p}=0.019$ ). Nevertheless, platelet count showed no significant difference between cases and controls.

Serum albumin showed a significant decrease in cases $(p=0.002)$. Other liver and kidney functions were comparable between cases and controls. Creactive protein showed a significant rise in cases compared to controls $(16.9$ vs. $3.02 \mathrm{mg} / \mathrm{dl}-\mathrm{p}<$ $0.001)$.

It was evident that the CDI rate was significantly higher in cases compared to controls $(\mathrm{p}=0.01)$, as it was detected in 16.25 and $2.5 \%$ of subjects in the same groups, respectively. The previous data are summarized in Table 1. 


\begin{tabular}{|c|c|c|c|}
\hline & $\begin{array}{c}\text { Cases }(\mathbf{n}= \\
80)\end{array}$ & $\begin{array}{c}\text { Controls } \\
(40)\end{array}$ & P value \\
\hline Age (years) & $\begin{array}{c}44.09 \pm \\
7.63\end{array}$ & $\begin{array}{c}45.72 \pm \\
8.57\end{array}$ & 0.326 \\
\hline $\begin{array}{l}\text { Gender } \\
\text { Males } \\
\text { Females }\end{array}$ & $\begin{array}{l}42(52.5 \%) \\
38(47.5 \%)\end{array}$ & $\begin{array}{l}22(55 \%) \\
18(45 \%)\end{array}$ & 0.192 \\
\hline BMI $(\mathrm{kg} / \mathrm{m} 2)$ & $\begin{array}{c}23.09 \pm \\
2.31\end{array}$ & $\begin{array}{c}28.72 \pm \\
3.44\end{array}$ & $0.035^{*}$ \\
\hline $\begin{array}{l}\text { Hemoglobin } \\
\text { (g/dl) }\end{array}$ & $8.30 \pm 1.39$ & $\begin{array}{c}11.33 \pm \\
2.63\end{array}$ & $0.015^{*}$ \\
\hline $\operatorname{PLTs}\left(10^{3} / \mu \mathrm{l}\right)$ & $\begin{array}{c}272.20 \pm \\
52.39\end{array}$ & $\begin{array}{c}259.60 \pm \\
40.35\end{array}$ & 0.143 \\
\hline WBCs $\left(10^{3} / \mathrm{ml}\right)$ & $\begin{array}{c}11.71 \pm \\
1.25\end{array}$ & $9.09 \pm 1.49$ & $0.019 *$ \\
\hline Albumin (g/dl) & $\begin{array}{c}2.98 \pm \\
0.21\end{array}$ & $\begin{array}{r}4.18 \pm \\
0.38\end{array}$ & $0.002 *$ \\
\hline $\begin{array}{l}\text { Creatinine } \\
(\mathrm{mg} / \mathrm{dl})\end{array}$ & $0.92 \pm 0.26$ & $0.94 \pm 0.27$ & 0.980 \\
\hline CRP (mg/l) & $16.9 \pm 3.7$ & $3.02 \pm 0.87$ & $0.001 *$ \\
\hline $\begin{array}{l}\text { Blood glucose } \\
\text { level (mg/dl) }\end{array}$ & $\begin{array}{c}122.79 \pm \\
15.51\end{array}$ & $\begin{array}{c}127.87 \pm \\
13.01\end{array}$ & 0.108 \\
\hline ALT (IU/ml) & $\begin{array}{c}28.08 \pm \\
5.83\end{array}$ & $\begin{array}{c}29.72 \pm \\
5.22\end{array}$ & 0.215 \\
\hline AST (IU/ml) & $28.01 \pm 6.41$ & $\begin{array}{c}27.70 \pm \\
5.20\end{array}$ & 0.378 \\
\hline CDI positivity & $\begin{array}{c}13 \\
(16.25 \%)\end{array}$ & $1(2.5 \%)$ & $0.010 *$ \\
\hline
\end{tabular}

*: significant p-value.

Table 1: Demographic and laboratory criteria between cases and controls.

We subdivided the included cases according to the positivity of CDI into two subgroups; the first subgroup included 67 cases that showed negativity for the test, while the remaining 13 cases showed its positivity. The prevalence of that infection was $16.25 \%$.

The mean age of the included cases in the two subgroups was 41.68 and 49.25 years in CDI -ve and $+v e$ groups, respectively $(\mathrm{p}=0.019)$. Unlike age, gender and BMI showed no significant difference between the two subgroups ( $p>0.05)$.

No significant difference was detected between the diseased subgroups regarding systemic comorbidities, clinical presentation, previous intestinal resections, and treatment regimens $(\mathrm{p}>$ $0.05)$. However, the duration of the disease showed a significant prolongation in the CDI +ve group $(\mathrm{p}=$ 0.001 ). Table (2) summarizes the previous data.

As shown in Table 3, all laboratory parameters showed no significant difference between the two cases subgroups $(p<0.05)$, apart from CRP that showed a significant elevation in cases with CDI. It had mean values of 18.42 and $12.51 \mathrm{~g} / \mathrm{dl}$ in CDI +ve and -ve cases respectively $(\mathrm{p}=0.002)$.

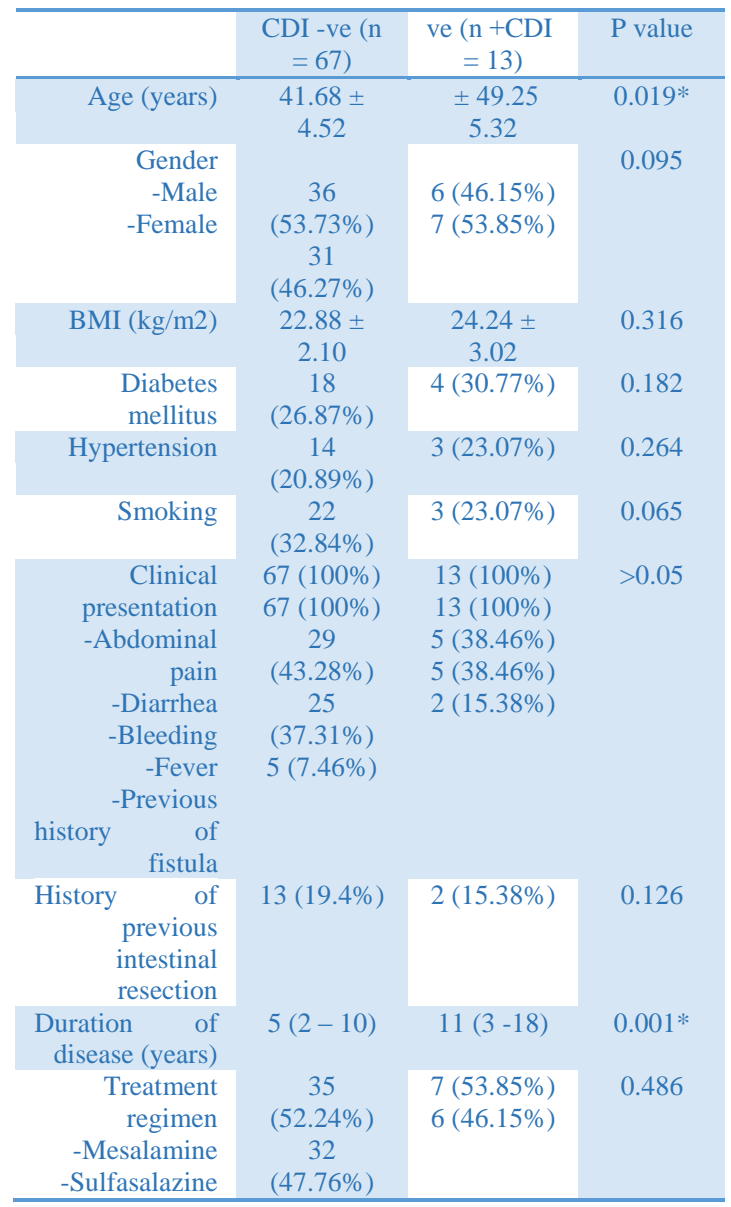

*: significant p-value.

Table 2: Demographic and clinical data of CDI +ve and -ve subgroups.

\begin{tabular}{|c|c|c|c|}
\hline & $\begin{array}{c}\text { CDI -ve }(n= \\
67)\end{array}$ & $\begin{array}{c}\text { ve }(n+C D I \\
=13)\end{array}$ & P value \\
\hline $\begin{array}{l}\text { Hemoglobin } \\
\text { (g/dl) }\end{array}$ & $8.46 \pm 1.61$ & \pm 0.968 .14 & 0.238 \\
\hline $\operatorname{PLTs}\left(10^{3} / \mu \mathrm{l}\right)$ & $282.11 \pm 49.6$ & $\begin{array}{c}261.5 \pm \\
53.12\end{array}$ & 0.109 \\
\hline $\begin{array}{l}\text { WBCs } \\
\left(10^{3} / \mathrm{ml}\right)\end{array}$ & $11.55 \pm 1.13$ & $11.87 \pm 1.40$ & 0.196 \\
\hline $\begin{array}{l}\text { Albumin } \\
\text { (g/dl) }\end{array}$ & $2.87 \pm 0.25$ & $2.95 \pm 0.18$ & 0.306 \\
\hline $\begin{array}{l}\text { Creatinine } \\
\text { (mg/dl) }\end{array}$ & $0.96 \pm 0.21$ & $0.89 \pm 0.34$ & 0.352 \\
\hline CRP (mg/l) & $12.51 \pm 1.69$ & $18.42 \pm 2.48$ & $0.002 *$ \\
\hline $\begin{array}{l}\text { Blood glucose } \\
\text { level (mg/dl) }\end{array}$ & $\begin{array}{c}127.56 \pm \\
17.81\end{array}$ & $\begin{array}{c}118.98 \pm \\
14.73\end{array}$ & 0.138 \\
\hline ALT (IU/ml) & $27.81 \pm 5.96$ & $29.47 \pm 5.70$ & 0.137 \\
\hline AST (IU/ml) & $29.60 \pm 6.52$ & $26.99 \pm 6.21$ & 0.149 \\
\hline
\end{tabular}

*: significant $\mathrm{p}$-value.

Table 3: Laboratory criteria in the study cases.

The type and extent of IBD did not show any significant difference between the two study subgroups. Conversely, disease severity showed a significant difference between the two subgroups ( $\mathrm{p}$ $=0.001)$, as severe cases were more encountered in $\mathrm{CDI}+\mathrm{ve}$ cases. 
There was a significant prolongation of hospital stay in cases that showed positivity for CDI ( $p<0.001$ ). Although only two cases required surgical intervention in the two subgroups, the incidence was significantly higher in the CDI +ve group (0.029).

\begin{tabular}{|c|c|c|c|}
\hline & $\begin{array}{c}\text { CDI -ve (n } \\
=67)\end{array}$ & $\begin{array}{c}\text { ve + CDI } \\
(\mathrm{n}=13)\end{array}$ & P value \\
\hline $\begin{array}{l}\text { Disease type } \\
\text {-UC } \\
\text {-CD }\end{array}$ & $\begin{array}{c}42 \\
(62.69 \%) \\
25 \\
(37.31 \%)\end{array}$ & $\begin{array}{l}7(53.85 \%) \\
6(46.15 \%)\end{array}$ & 0.067 \\
\hline $\begin{array}{l}\text { Disease extent } \\
\text {-L1 or E1 } \\
\text {-L2 or E2 } \\
-L 3 \text { or E3 }\end{array}$ & $\begin{array}{c}40(59.7 \%) \\
16 \\
(23.88 \%) \\
11 \\
(16.42 \%)\end{array}$ & $\begin{array}{c}7(53.8 \%) \\
3(23.07 \%) \\
3(23.07 \%)\end{array}$ & 0.090 \\
\hline $\begin{array}{l}\text { Disease severity } \\
\text {-Mild } \\
\text {-Moderate } \\
\text {-Severe }\end{array}$ & $\begin{array}{c}31 \\
(46.26 \%) \\
21 \\
(31.34 \%) \\
15 \\
(22.38 \%)\end{array}$ & $\begin{array}{l}4(30.77 \%) \\
3(23.07 \%) \\
6(46.15 \%)\end{array}$ & $0.001 *$ \\
\hline $\begin{array}{l}\text { Duration of } \\
\text { hospitalization } \\
\text { (days) }\end{array}$ & $7(2-12)$ & $15(4-26)$ & $<0.001 *$ \\
\hline $\begin{array}{l}\text { Need for } \\
\text { surgical } \\
\text { intervention }\end{array}$ & $2(2.98 \%)$ & $2(15.38 \%)$ & $0.029^{*}$ \\
\hline Mortality & $0(0 \%)$ & $0(0 \%)$ & 1 \\
\hline
\end{tabular}

*: significant $\mathrm{p}$ value.

Table 4: Disease criteria and outcomes in CDI +ve and -ve subgroups.

On regression analysis to detect the risk factors for having CDI in IBD cases (table 5), old age, long disease duration, severe disease, and high CRP levels were risk factors for CDI on univariate analysis. All of these variables remained significant on multivariate analysis apart from disease duration.

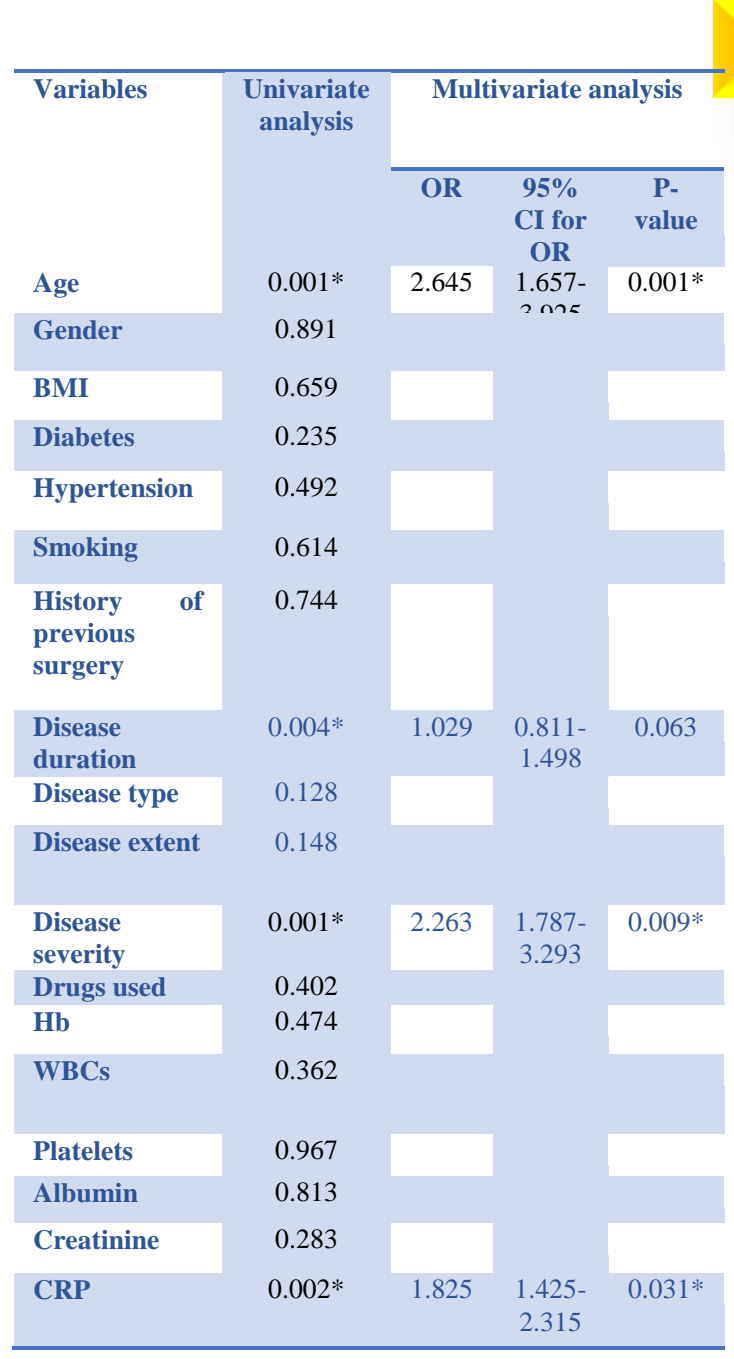

*: significant $\mathrm{p}$ value.

Table 5: Regression analysis to detect the risk factors for having CDI in IBD cases.

\section{DISCUSSION}

This study was conducted to estimate the prevalence and risk factors of CDI in cases with IBD. We encountered 13 patients in the cases group showing positivity for CDI (16.25\%), compared to only one control $(2.5 \%)$. It was evident that there is an increased rate of CDI in cases diagnosed with IBD. Compared to the general population, multiple studies have shown an increase in CDI frequency in patients with IBD. ${ }^{13,15,17,24}$ This confirms our findings.

Our incidence is higher than the one reported by previous studies, which ranged between 3 and $6 \%$. ${ }^{13}$,

15, 17 Nevertheless, it is following Zhang and his colleagues, who reported that CDI was detected in 99 out of 646 cases with IBD $(15.32 \%) .{ }^{25}$ Other authors reported much higher Prevalence, as CDI was detected in 20 out of 81 cases $(24.7 \%){ }^{\mathbf{2 6}}$

Little is known about the role of asymptomatic C. difficile colonization and its progression to CDI. Clostridium colonization occurs at a rate of $20 \%$ to $40 \%$ in hospitalized people, compared to $2 \%$ to $3 \%$ in healthy persons. ${ }^{27,}{ }^{28}$ The previous reports agree with our findings regarding the prevalence of CDI in the control group. 
In our study, C-reactive protein showed a significant rise in cases compared to controls ( $p<0.001$ ). Erbayrak and his colleagues showed that CRP levels were considerably higher in IBD cases compared to controls ( $p<0.05$ ), which is consistent with our findings. CRP levels in $\mathrm{UC}, \mathrm{CD}$, and controls were $17.53,33.83$, and $4.28 \mathrm{mg} / \mathrm{dl}$, respectively. ${ }^{29}$

Based on CDI test findings, the study cases were subdivided into two subgroups; the first one included 67 cases that showed negativity for CDI, while the other one included the remaining 13 cases that showed positivity for CDI. Old age was also a significant risk factor for CDI infection on univariate and multivariate analyses $(p=0.001)$. In line with our findings, a statewide prospective populationbased investigation in Sweden found that the rate of CDI was ten times greater in people over 65 than in people under the age of $20 .{ }^{30}$

Several facts could explain this phenomenon. First, a weakened innate or humoral immune response may increase the frequency and severity of CDI. ${ }^{31,32}$ Also, the increased occurrence of CDI in the elderly could be linked to changes in intestinal microbial composition. ${ }^{33,}{ }^{34}$ Furthermore, chronic diseases and an increase in infection rates, necessitating polypharmacy, including antibiotics, are much more common in this age group. ${ }^{35,36}$

In the current study, the duration of the disease showed a significant prolongation in the CDI +ve group compared to CDI -ve cases $(p=0.001)$. Long disease duration was a significant risk factor for CDI on univariate analysis $(\mathrm{p}=0.004)$. We think that might agree with our findings regarding age, as old age is often associated with long disease duration. Another study negated any significant differences between CDI +ve and -ve cases regarding the duration of the disease $(p=0.647)$. It had median values of 55 and 84 months in CDI +ve and -ve cases, respectively. ${ }^{37}$

Our findings showed that disease extent did not have a significant impact on developing CDI $(\mathrm{p}=0.98)$. Also, Zhang et al. negated any significant impact of disease location on the development of CDI in IBD cases $(p>0.05) .{ }^{25}$ Maharshak et al. also denied any significant impact of disease extent on developing CDI in IBD cases neither in UC or CD cases.

In the current study, severe disease was a strong predictor of having CDI on both univariate and multivariate analyses $(\mathrm{p}=0.001$ and 0.009 , respectively). In line with our findings, another study reported that all CDI cases had moderate to severe disease $(100 \%)$, while only $30 \%$ had the same stage in CDI -ve group $(\mathrm{p}=0.001) .{ }^{38}$

Our study detected no significant difference between the two subgroups regarding the treatment regimen commenced for IBD. In another study, authors negated any significant impact of mesalamine administration on CDI development ( $\mathrm{p}=0.47)$, as it was reported by 64.1 and $71.8 \%$ of cases in CDI +ve and -ve cases, respectively. ${ }^{39}$

The Prevalence of fever did not show a significant difference between the two subgroups $(\mathrm{p}=0.835)$, which was present in 37.31 and $38.46 \%$ of cases in CDI -ve and +ve, respectively. On the contrary, another study reported a higher Prevalence of fever in cases with CDI than those who did not $(\mathrm{p}=0.049)$. Fever was detected in 27 and $0 \%$ of cases in the two groups, respectively. ${ }^{37}$

In our research, there was no significant difference between the two groups in terms of the previous history of fistula $(\mathrm{p}=0.074)$, which was found in 7.46 and 15.38 percent of CDI -ve and +ve cases, respectively. Another study reported that the CDI +ve group included $30.6 \%$ of its cases with fistula, versus only $15.1 \%$ of cases in the CDI -ve group, with a significant difference between the two groups. 25

In the current study, no significant difference was detected between the two groups regarding total leucocytic count $(\mathrm{p}=0.196)$, which had mean values of 11.55 and 11.87 in CDI -ve and +ve groups, respectively. Kariv et al. also reported no significant difference between CDI +ve and -ve cases regarding WBCs $(\mathrm{p}=0.49)$, which had median values of 11.5 and $8.7 \times 10^{9}$ cells/l in the two groups, respectively. ${ }^{39}$

In our study, CRP showed a significant elevation in cases with CDI $(p=0.002)$. Increased CRP was a significant predictor of CDI in cases with IBD on both univariate and multivariate analysis. This could be explained by disease severity in both groups. As mentioned before, disease severity was significantly increased in CDI +ve cases, and it was previously reported that there is a significant correlation between CRP levels and histological findings in IBD. ${ }^{40,41}$

In the current study, there was a significant prolongation of hospital stay in cases that showed positivity for CDI $(\mathrm{p}<0.001)$. Multiple studies others highlighted the longer stays than in IBD patients with CDI compared to those who did not. ${ }^{15}$, 17, 19, 24, 42 On the other hand, others reported similar stays ${ }^{13,16}$ and reported some shorter ones. ${ }^{18}$

In our study, although only two cases required surgical intervention in the two subgroups, the incidence was significantly higher in the CDI +ve group (0.029). Other studies have found that CDI in IBD patients is associated with a higher colectomy rate than IBD patients without CDI or those with CDI alone. ${ }^{16,42,43}$

In our study, we reported no mortality in the included cases. Likewise, no deaths were reported by Bossuyt et al. among their UC and CDI patients. ${ }^{18}$ From 1998 to 2007, Ananthakrishnan et al. found a nonsignificant increase in the relative mortality risk in IBD patients with superimposed CDI $(\mathrm{OR}=2.38, \mathrm{CI}$ : 1.52-3.72). ${ }^{43}$ On the other hand, multiple other studies reported that mortality rates are higher in IBD patients with CDI than in those without CDI or with CDI alone. ${ }^{17,19,42}$

Our research has some limitations. First and foremost, our study is a single-center study with small sample size. Also, the financial cost of CDI infection should have been evaluated. 


\section{CONCLUSION}

The Prevalence of CDI is higher in IBD cases than the normal population. The Prevalence CDI in the selected sample was $16.25 \%$. Old age, long disease duration, high CRP, and high disease activity are strong risk factors of $\mathrm{CDI}$ in IBD patients. In addition, CDI has a significant negative impact on IBD cases as it is associated with more extended hospitalization and an increased need for surgical intervention.

\section{REFERENCES}

1. Moens A, Verstockt B, Machiels $\mathrm{K}$, et al Clostridium difficile infection in inflammatory bowel disease: epidemiology over two decades. European journal of gastroenterology \& hepatology. 2019;31(6):668-73.

2. Tang YM and Stone CD. Clostridium difficile infection in inflammatory bowel disease: challenges in diagnosis and treatment. Clinical journal of gastroenterology. 2017;10(2):11223.

3. van der Sloot KW, Amini M, Peters V, et al Inflammatory bowel diseases: review of known environmental protective and risk factors involved. Inflammatory bowel diseases. 2017;23(9):1499-509.

4. Ramos GP, Papadakis KA, editors. Mechanisms of disease: inflammatory bowel diseases. Mayo Clinic Proceedings; 2019: Elsevier.

5. Trifan A, Stanciu C, Stoica O, et al. Impact of Clostridium difficile infection on inflammatory bowel disease outcome: a review. World Journal of Gastroenterology: WJG. 2014;20 (33): 11736

6. Lamont JT and Trnka Y. Therapeutic implications of Clostridium difficile toxin during relapse of chronic inflammatory bowel disease. The Lancet. 1980;315(8165):381-3.

7. Rodríguez C, Romero E, Garrido-Sanchez L, et al. Microbiota insights in Clostridium difficile infection and inflammatory bowel disease. Gut Microbes. 2020;12(1):1725220.

8. Maharshak N, Barzilay I, Zinger $\mathrm{H}$, et al Clostridium difficile infection in hospitalized patients with inflammatory bowel disease: Prevalence, risk factors, and prognosis. Medicine. 2018;97(5).

9. Stallmach A, Anttila V-J, Hell M, et al Inflammatory bowel disease and Clostridium difficile infection: contrasting views of international clinical professionals. Zeitschrift für Gastroenterologie. 2018;56(07):731-7.
10. Balram B, Battat R, Al-Khoury A, et al. Risk factors associated with Clostridium difficile infection in inflammatory bowel disease: a systematic review and meta-analysis. Journal of Crohn's and Colitis. 2019;13(1):27-38.

11. Cojocariu C, Stanciu C, Stoica O, et al. Clostridium difficile infection and inflammatory bowel disease. Turk $J$ Gastroenterol. 2014;25(6):603-10.

12. Warny M and Kelly CP. Pathogenicity of Clostridium difficile toxins. Microbial pathogenesis and the intestinal epithelial cell. 2003:503-24

13. Rodemann JF, Dubberke ER, Reske KA, et al. Incidence of Clostridium difficile infection in inflammatory bowel disease. Clinical Gastroenterology and Hepatology. 2007;5(3):339-44.

14. Khanna S, Shin A and Kelly CP. Management of Clostridium difficile infection in inflammatory bowel disease: expert review from the clinical practice updates committee of the AGA institute. Clinical Gastroenterology and Hepatology. 2017;15(2):166-74.

15. Issa M, Vijayapal A, Graham MB, et al. Impact of Clostridium difficile on inflammatory bowel disease. Clinical Gastroenterology and Hepatology. 2007;5(3):345-51.

16. Jodorkovsky D, Young $\mathrm{Y}$ and Abreu MT. Clinical outcomes of patients with ulcerative colitis and co-existing Clostridium difficile infection. Digestive diseases and sciences. 2010;55(2):415-20.

17. Nguyen GC, Kaplan GG, Harris ML, et al. A national survey of the prevalence and impact of Clostridium difficile infection among hospitalized inflammatory bowel disease patients. American Journal of Gastroenterology. 2008;103(6):1443-50.

18. Bossuyt P, Verhaegen J, Van Assche G, et al. Increasing incidence of Clostridium difficileassociated diarrhea in inflammatory bowel disease. Journal of Crohn's and Colitis. 2009;3(1):4-7.

19. Murthy S, Steinhart A, Tinmouth J, et al. Impact of Clostridium difficile colitis on 5-year health outcomes in patients with ulcerative colitis. Alimentary pharmacology \& therapeutics. 2012;36(11-12):1032-9.

20. Choi CH, Moon W, Kim YS, et al. Second Korean guidelines for the management of ulcerative colitis. Intestinal research. 2017;15(1):7. 
21. Park JJ, Yang S-K, Ye BD, et al. Second Korean guidelines for the management of Crohn's disease. Intestinal research. 2017;15(1):38.

22. Mowat C, Cole A, Windsor A, et al. Guidelines for the management of inflammatory bowel disease in adults. Gut. 2011;60(5):571-607.

23. Satsangi J, Silverberg M, Vermeire S, et al. The Montreal classification of inflammatory bowel disease: controversies, consensus, and implications. Gut. 2006;55(6):749-53.

24. Ananthakrishnan AN, McGinley EL and Binion DG. Excess hospitalisation burden associated with Clostridium difficile in patients with inflammatory bowel disease. Gut. 2008;57(2):205-10.

25. Zhang T, Lin Q-Y, Fei J-X, et al. Clostridium difficile infection worsen outcome of hospitalized patients with inflammatory bowel disease. Scientific reports. 2016;6(1):1-9.

26. Pascarella F, Martinelli M, Miele E, et al. Impact of Clostridium difficile infection on pediatric inflammatory bowel disease. The Journal of pediatrics. 2009;154(6):854-8.

27. Viscidi $\mathrm{R}$, Willey $\mathrm{S}$ and Bartlett JG. Isolation rates and toxigenic potential of Clostridium difficile isolates from various patient populations. Gastroenterology. 1981;81(1):5-9.

28. McFarland LV, Mulligan ME, Kwok RY, et al. Nosocomial acquisition of Clostridium difficile infection. New England journal of medicine. 1989;320(4):204-10.

29. Erbayrak M, Turkay C, Eraslan E, et al. The role of fecal calprotectin in investigating inflammatory bowel diseases. Clinics. 2009;64(5):421-5.

30. Karlström O, Fryklund B, Tullus $\mathrm{K}$, et al. A prospective nationwide study of Clostridium difficile-associated diarrhea in Sweden. Clinical Infectious Diseases. 1998;26(1):141-5.

31. Mariat D, Firmesse O, Levenez F, Guimarăes V, et al. The Firmicutes/Bacteroidetes ratio of the human microbiota changes with age. $B M C$ microbiology. 2009;9(1):1-6.

32. Ogra PL. Ageing and its possible impact on mucosal immune responses. Ageing research reviews. 2010;9(2):101-6.

33. Woodmansey EJ. Intestinal bacteria and ageing. Journal of applied microbiology. 2007;102(5):1178-86.
34. Hopkins M, Sharp R and Macfarlane G. Age and disease related changes in intestinal bacterial populations assessed by cell culture, 16S rRNA abundance, and community cellular fatty acid profiles. Gut. 2001;48(2):198-205.

35. Werner $\mathrm{H}$ and Kuntsche $\mathrm{J}$. Infection in the elderly--what is different? Zeitschrift fur Gerontologie und Geriatrie. 2000;33(5):350-6.

36. Gao L, Maidment I, Matthews FE, et al. Medication usage change in older people (65+) in England over 20 years: findings from CFAS I and CFAS II. Age and ageing. 2018;47(2):220-5.

37. Ramos-Martínez A, Ortiz-Balbuena J, CurtoGarcía I, et al. Risk factors for Clostridium difficile diarrhea in patients with inflammatory bowel disease. Rev Esp Enferm Dig. 2015;107(1):4-8.

38. Shoaei P, Shojaei H, Jalali M, et al. Clostridium difficile isolated from faecal samples in patients with ulcerative colitis. BMC infectious diseases. 2019;19(1):1-7.

39. Kariv R, Navaneethan U, Venkatesh PG, et al. Impact of Clostridium difficile infection in patients with ulcerative colitis. Journal of Crohn's and Colitis. 2011;5(1):34-40.

40. Solem CA, Loftus Jr EV, Tremaine WJ, et al. Correlation of $\mathrm{C}$-reactive protein with clinical, endoscopic, histologic, and radiographic activity in inflammatory bowel disease. Inflammatory bowel diseases. 2005;11(8):707-12

41. Alper A, Zhang L and Pashankar DS. Correlation of erythrocyte sedimentation rate and Creactive protein with pediatric inflammatory bowel disease activity. Journal of pediatric gastroenterology and nutrition. 2017;65(2):e25-e7.

42. Jen MH, Saxena S, Bottle A, et al. Increased health burden associated with Clostridium difficile diarrhoea in patients with inflammatory bowel disease. Alimentary pharmacology \& therapeutics. 2011;33(12):1322-31.

43. Ananthakrishnan AN, McGinley EL, Saeian K, et al. Temporal trends in disease outcomes related to Clostridium difficile infection in patients with inflammatory bowel disease. Inflammatory bowel diseases. 2011;17(4):97683. 